\title{
A Model of Doctor-Patient Communication and Information Seeking a Study Among Trainee or Junior Doctors in Malaysian Hospital
}

\author{
Hashim Fauzy Yaacob, Zaidatul Nadiah Abu Yazid \\ School of Human Resource Development and Psychology, Faculty of Social Sciences and Humanities, Universiti Teknologi Malaysia, 81310 UTM Johor \\ Bahru, Johor, Malaysia \\ *Corresponding author: hfauzy@utm.my
}

Article history: Received: 10 May 2020 Received in revised form: 06 May 2021 Accepted: 15 May 2021 Published online: 31 August 2021

\begin{abstract}
The purpose of this study is to evaluate the doctors-patients communication style and their information seeking practiced among doctors under training or junior doctors in Malaysian hospital. Two types of communication styles evaluated are doctor centered and patient centered communication. Meanwhile, elements of information seeking practice evaluated are exploration of the reason for encounter, history taking, concrete solutions, structuring the interview, interpersonal skills and communicative skills. These six elements were categorized into interview skills and process skills. This information seeking skills have been derived from meta-analysis conducted by Stewart and Roter (1989). We combined the doctors-patients communication style and information seeking practice to develop a model based on four quadrants namely doctors-interview, doctors-process, patient-interview and patient-process. The subjects for this research are doctors under training or junior doctors in Malaysia. This explorative research distributed a set of questionnaires in order to collect data for analysis. The result show that the doctors under training or junior doctors tend to practice doctor-centered styles compare to patient-centered. Meanwhile, most of them demonstrate all the information seeking practice at a high level. Based on four quadrants developed by researcher, research shows that the doctors mostly categorized in doctor-centered communication style and interview information-seeking skills. We suggested that doctors should be more patient-oriented rather than doctor oriented. We also suggested the model that we developed can be used as a model of communication pattern of the doctors and can be used for future research.
\end{abstract}

Keywords: Communication, doctors, patient, communication styles, information seeking.

\begin{abstract}
Abstrak
Tujuan kajian ini adalah untuk menilai gaya komunikasi doktor-pesakit dan pencarian maklumat yang diamalkan dalam kalangan doktor pelatih atau doktor junior di hospital Malaysia. Dua jenis gaya komunikasi yang dinilai adalah komunikasi berpusatkan doktor dan berpusatkan pesakit. Sementara itu, elemen pencarian maklumat yang dinilai adalah penerokaan,, mengambil sejarah, penyelesaian konkrit, temutanya berstruktur, kemahiran interpersonal dan kemahiran komunikasi. Keenam elemen ini dikategorikan ke dalam kemahiran temutanya dan kemahiran proses. Kemahiran mencari maklumat ini berasal dari analisis meta yang dilakukan oleh Stewart dan Roter (1989). Kami menggabungkan gaya komunikasi doktor dan amalan mencari maklumat untuk mengembangkan model berdasarkan empat kuadran iaitu doktor-temutanya, doktor-proses, pesakit-temutanya dan pesakit-proses. Subjek untuk penyelidikan ini adalah doktor pelatih atau doktor junior di Malaysia. Penyelidikan eksploratif dilakukan dengan mengedarkan satu set soal selidik untuk mengumpulkan data bagi dianalisis. Hasilnya menunjukkan bahawa doktor yang menjalani latihan atau doktor junior cenderung untuk mengamalkan gaya berpusatkan doktor berbanding dengan berpusatkan pesakit. Sementara itu, kebanyakan mereka menunjukkan semua amalan mencari maklumat pada tahap tinggi. Berdasarkan empat kuadran yang dikembangkan oleh penyelidik, penyelidikan menunjukkan bahawa doktor kebanyakannya dikategorikan dalam gaya komunikasi berpusatkan doktor dan kemahiran mencari maklumat temutanya. Kami mencadangkan agar doktor lebih berorientasikan pesakit daripada doktor. Kami juga mencadangkan model yang kami kembangkan dapat dijadikan model corak komunikasi para doktor dan dapat digunakan untuk kajian masa hadapan
\end{abstract}

Kata kunci: Komunikasi, doktor, pesakit, gaya komunikasi, pencarian maklumat.

(C) 2021 Penerbit UTM Press. All rights reserved

\subsection{INTRODUCTION}

The traditional medical field give a little attention to social interest because they defining disease from a biological standpoint (Powell \& Amsbary, 2006). But modern medicine, as practiced today, is witnessing the introduction of a patient-centered approach in the diagnosis and treatment of disease (Gordon, 2020). This approach needs a good communication skill including process of intervention, information seeking skills and interviews skills (Abor, 2019). Ineffective doctor-patient communication will tend to doctors lose their focus on holistic patient care including the patient trust, satisfaction and medical positive outcomes such as increase adherence and compliance, adjustment of expectations, self-regulation and better coping (Platonova \& Shewchuck, 2015; Blasen \& Blasen, 2018; Abor, 2019)

As a result, medical schools place much emphasis on the subject of communication skills among their students and consultants, which has led to the establishment of programs to evaluate doctor-patient relationships (Hildenbrand et al 2020. Most medical schools in the world 
offer courses on communication skills to their students (Novack, et.al, 1993; Choudhary \& Gupta, 2015; Taveira-Gomesa, Morta-Cardosoa \& Figueiredo-Bragaa, 2016; Graf et.al, 2020), but this is not taken seriously by trained, experienced doctors who have worked at hospitals around the country (Smith \& Hoppe, 1991).

Therefore, this study will collect data and findings related to identify (i) the doctor-patient communication style adopted by junior doctors (ii) the level of information seeking skills adopted by junior doctors and (iii) dominant patterns of doctor-patient communication styles and information seeking practice adopted by junior doctors.

\subsection{LITERATURE REVIEW}

The information seeking behavior among doctors has been extensively studied since 1940s, because work in healthcare environment, a doctor's responsibility is to treat patient. According to Robson and Robinson (2015) "To decide on a diagnosis an appropriate treatment for a particular patient, a doctor needs information, and this need may lead to information seeking behavior. The information including the patients' attitude towards health. Attitude is the expectation that patients have of medical practitioners and the health care system, including self-perception and constraints related to the condition itself, and the importance of morals and attitudes towards life style changes. The think that a medical practitioner who ignores the sign of diseases, as suffered by their patients, will be overlooking important information and healing tools. Model-centred information that the healing process can be improved when doctors and patients understand each other implies that the goal of healing and the roles which must be played by patients and doctors are closely intertwined. In short, each step in the process of health care begins with a clear understanding of patient attitudes.

Medical interviews themselves may affect the patients' personal and health problems. Accurate information about the health status of patients is very important in order to carry out the diagnosis of disease in injury. Hence in interview, doctors needs for active and emphatic listening, appropriate questioning and provision of adequate instructions and relevant information to patient (Platonova \& Shewchuck, 2015). This information leads to appropriate treatment, further strengthening the relationship between doctor and patient (Suchman, Markakis, Beckman \& Frankel, 1997).

The medical interview process begins when the receptionist asks important questions concerning such items as contact information, past medical records, and insurance coverage (Powell \& Amsbary, 2006). The process continues when the nurses interview patients to obtain preliminary information related to patient's health problems. The significance of the information gathering process is more profound when the doctor arrives. The doctor will examine the patient and ask about the medical records of the past and signs of illness suffered by the patients themselves.

The objectives of the doctor-patient relationship can be achieved through the cooperation of both parties working together to improve the health status of patients (Young \& Flower, 2001). The attitude of doctors, when communicating with their patients, showed that a direct relationship exists, stemming from the initial meeting between doctors and their patients (Graugaard \& Finset, 2000). Proof of this can be seen clearly in research related to patient satisfaction and adherence to goals (DiMatteo et al, 1993). However, most studies conducted in in recent years show that the communication process between doctor and patient can also influence the patient's psychological and physical wellbeing (Stewart, 1995; Platonova \& Shewchuck, 2015; Cerimagi et. al, 2015; Blasen \& Blasen, 2018; Abor, 2019; Wu \& Street Jr., 2020).

It is important that all parties, especially the patient, recognize that the obligation to provide useful information during the interview rests with the patients themselves (Ballard-Reisch, 1990; Manning \& Ray, 2002). That is why patients who have medical training, and are familiar with interview techniques, are able to provide more information in interviews with medical officers, and medical officers then find it much easier to understand the real problems they face (Weaver, 2003). Patients who are less actively involved in the interview process with their doctors tend to give less information related to the problems they face (Robinson, 2003).

Interviews are the most important foundation in the medical field. During the interview, doctors not only have the opportunity to learn about the problems being experienced by their patients, but they also have an opportunity to strengthen the doctor-patient relationship (Hersen \& Turner, 2003). In addition, an interview process enables the doctor to obtain important information needed to enable them make to make a decision relating to medical diagnosis. The general thinking is that a doctor will not be a good diagnostician or physician if he does not have good interview skills. Indeed, physicians with poor interview skills tend to make decisions that may threaten the health of their patients.

Most training programs offer little in the way of interview topics. To be a good interviewer requires a high level of knowledge in the field of psychopathology as well as knowledge of current diagnostic schemes, enabling the doctor to assess the information obtained from the patient. In addition, doctor also need to possess social communication skills, and be sensitive to the needs of their patients so as to better obtain the cooperation of the patient. Communication skills is needed by doctors because poor communication by doctors increases the pressure felt by patients (Takayama, Yamazaki \& Katsumata, 2002), causing patients to express dissatisfaction with their doctor (Virshup, Oppenberg \& Coleman, 1999), or to change their health centre (Safran, Montgomery, Chang, Murphy \& Rogers, 2001).

Based on these evidences, during the 1980s, the doctor-patient relationship received special attention from various parties, and the introduction of audio and video systems allowed researchers to explore advanced topics that did not seem serious in-depth (Marvel, Epstein, Flowers \& Beckman, 1999). One of the most extensive studies referred to at this time, as conducted by Beckman and Frankel (1984), reported that patients often answer questions based on questions raised by the doctor. They also indicated that consequence of the controlled style by doctors, resulting in the potential loss of relevant information.

\subsection{METHODOLOGY}

This study used quantitative survey methods using questionnaires. Variables studied were two elements of communication (i) communication style, and (ii) information seeking practice. According to studies by Smith et al (1998), Symone et al (2001), Stewart et al 
(2007), Graugaard and Finset (2000), and Laerum et al (2002), there are two communication styles that govern communication between doctor and patient. These styles are doctor-centered communication and patient centered communication.

The elements of the variables studied in information seeking are divided into two approaches, interview skills and process skills. Information seeking skills have been derived from meta-analysis conducted by Stewart and Roter (1989). Based on the meta-analysis carried out, they have identified 247 different variables that could be used in the study of communication skills. These variables were grouped into six categories, with each category sharing similarities between the provision of information (information giving), retrieval of information (information seeking) social conversation, talk positive, negative talk and also partnership-building.

Information seeking skills undertaken by the respondents of this survey will be evaluated based on the six elements that have been identified. These six elements are exploration, history taking, concrete solution, structuring interview, interpersonal relationships and communicative skills. Exploration, history taking and concrete solution are classified as interview skills, and structuring interview, interpersonal relationship and communicative skills as process skills.

Exploration: The purpose of this phase is to obtain information from the patients themselves concerning their health history, and the causes of pain stemming from the health problems they are facing at the time. Medical practitioners give the patient the chance to convey information, feelings, complaints and opinions in their own words about their disease, In addition, doctors will provide opportunities for patients to specify the causes and effects of the disease that caused them to arrange a meeting with medical practitioners in the first place.

History-taking: In this section, the patient will be asked a series of medical questions. The questions asked relate to the characteristics of pain, the location of the pain, the location of the pain, previous diseases and any received treatment, medications taken etc. In this section, the doctor will try to obtain information related to psychosocial issues such as the patient's interpersonal relationship with the community, family background, career and leisure time, significant events that have occurred in the lives of patients and others.

Concrete solution: After conducting a physical examination, the doctor will inform the patient of their actual state of health as well as provide a diagnosis of the cause of the pain. The doctor will the try to gauge how the patients feel now that they know more about what is ailing them. Finally, the doctor and patient may discuss appropriate treatment to combat the disease.

Structuring interviews: This phase of evaluation deals with how doctors can conduct more effective interviews. Important elements to be studied in this section include an assessment of how doctors begin and end a patient interview. This phase also investigates the degree to which the doctor is aware of the phases previously discussed.

Interpersonal relationship skills: Interpersonal relationship skills refer to behaviours that strengthen the relationship between doctor and patient, including trust and acceptance, which are believed to be very important when measuring patient satisfaction. Among the features included in the interview skills are empathy, friendliness and caring, being an active listener, being the facilitator, always being positive and having an open attitude.

Communicative skills: Communicative skills are concerned with the sharing of information between doctors and patients. Questioning techniques, and the ability to provide information and advice, constitute a large component of communication skills.

\subsection{Research Framework}

In this study, the researcher has developed a quadrant-shaped model to study the pattern of behaviour by the respondents (Figure 1). Quadrants A and B are doctor centered communication style categories, and Quadrants C and D represent patient centered communication styles. Respondents in this study classified into one of these four categories based on the results obtained from the information search procedure as conducted with their patients. Next, based on literature, six variables of information seeking skills are categorized into two types of information seeking skills, namely interview skills and process skills. Exploration, history taking and concrete solution are categorized as interview skills and structuring interviews, interpersonal relationship skills and communicative skills are categorized as process skills. The data obtained in this study will be presented in the form of percentages based on responses given by respondents.

Quadrant A: Doctor-centered communication style combined with information seeking-interview. Doctor-centered communication implies that doctors exercise a large measure of control in communication sessions with patients. Medical information and advice on how to prevent a recurrence of the disease is given to the patient. Practicing information seeking skills involves searching for information that is specialized in nature, for example, the specific type of disease and the pain experienced by the patient. Doctors often use close questions and provide advice to their patients, but do not give much of an opportunity for their patients to become involved in the communication process.

Quadrant B: Doctor-centered communication style combined with the information seeking-process. Doctor centered communication features a great deal of control, by the doctor, over the communication session with their patients. Medical information and advice on how to prevent a recurrence of the disease are given to the patient. Other features include a skill information seeking process, in which more doctors use good communication skills such as trying to create a more comfortable environment for patients, or making their patients motivated to work with the respondent to provide the information required by the respondents to understand the patient's condition. Doctors make more extensive use of closed questions and provide advice to their patients, but do not give much room for their patients to be involved in the communication process. Displays of empathy and emotion on behalf of the doctor are valuable assets here.

\begin{tabular}{|c|c|}
\hline $\begin{array}{c}\text { A } \\
\text { (Doctors-Interview) } \\
\text { Doctor centered - Information seeking } \\
\text { (interview) }\end{array}$ & $\begin{array}{c}\text { B } \\
\text { (Doctors-Process) } \\
\text { C }\end{array}$ \\
\hline $\begin{array}{c}\text { (Patient-Interview) } \\
\text { Poctor centered-Information seeking } \\
\text { (process) }\end{array}$ \\
$\begin{array}{c}\text { D } \\
\text { Patient centered-Information seeking } \\
\text { (Interview) }\end{array}$ & $\begin{array}{c}\text { (Patient-Process) } \\
\text { Patient centered-Information seeking } \\
\text { (Process) }\end{array}$ \\
\hline
\end{tabular}

Figure 1 Communication and Information Seeking Model 
Quadrant C: Patient-centered communication style, combined with information seeking-interview, yields greater opportunities to interact with their patients and provide information related to the problems they face. Information seeking practiced in this quadrant include specializing in the type disease and pain experienced by their patients. Doctors usually make extensive use of open-ended questions, and provide more opportunities for their patients to become involved in the communication process between doctor and patient.

Quadrant D: Patient-centered communication style combined with the information seeking-process. Information seeking practice is to process information searching skills. Doctors see that the good communication skills, such as working to establish a more comfortable environment for patients, tend to make their patients work with the doctor to provide the information needed to better understand the patient's condition. Doctors in this category often use open ended questions, providing more opportunities for their patients to participate in the communication process. Doctors in this quadrant are good at displaying empathy and emotion.

\subsection{Location And Population Studies}

The study was conducted at Malaysian hospitals in Negeri Sembilan Malaysia, a hospital which provides services in General Medicine, Surgery, Obstetrics and Gynaecology (O \& G), Paediatric, Orthopaedics, Anaesthesiology, Psychiatry and Accident and Emergency. In addition, the hospital also provides haemodialysis to patients. The hospital provides medical services to 200,000 residents. The population for this study consisted of 74 housemanship or junior doctors. Housemanship doctors or junior doctors are doctors who are appointed in the hospital after their graduation in medical field at least at undergraduate level. In Malaysia they have to go through the process for two years. The junior doctors will serve in six departments namely, Internal Medicine, General Surgery, Pediatrics, O \& G, Orthopaedics and Emergency Medicine \& Trauma or Surgery before being appointed as a qualified doctor. However, if they fail within five years they will be terminated from the position as medical doctor. Due to the small size of the study population, all 74 junior doctors were selected by the researchers as research subjects.

\subsection{Research Instruments}

One set of research instrument were used in a Part A (respondent's background), Part B (communication style) and Part C (information seeking). Part A consists of six questions, while Section B consists of eight questions designed to determine the communication style. Items list in this section were formed by Tate (2007). Part C contains 68 questions from Stewart and Roter (1989). Items in this section can be divided into two parts, interview skills and process skills. Among the elements under study is exploration, history taking, the concrete solution, the structuring interview, interpersonal skills as well as communicative skills. To test the instrument, a pilot study was conducted among junior doctors at a government hospital in Johor, Malaysia which has similar to the actual population in the study. Cronbach Alpha analysis was done to determine the reliability of the instrument.

\subsection{Data Collection and Data Analysis}

Questionnaires were distributed to 74 respondents at hospital in Negeri Sembilan Malaysia. The percentage of questionnaire returned to the researcher is $100 \%$. Analysis of scores used to determine the level of agreement for each statement in connection with communication or information seeking between the doctors and patients is based on mean. To obtain the percentage to matched into the quadrant, the respondent's mean score divided by the highest mean and multiply by 100 . Data obtained from questionnaire Part B and Part C are used to plot the quadrant that was built for the communication pattern adopted by the respondents.

\subsection{RESULTS}

From the 74 junior doctors, $48.6 \%$ are male and $51.4 \%$ are female. The majority or $74 \%$ are between 25 to 27 years old and $26 \%$ either below 25 or above 29 . Most of them have less than one year work experience and only $42 \%$ more than two years.

\subsection{Communication Style: Doctor Centered or Patient Centered}

Based on Table 1, it was found that a majority of the respondents (59/74 or 79.7\%) practice doctor-centered communication in the medium range. These doctors believe that to obtain the information needed to help patients seeking treatment, building relationships and gaining the trust of these patients seeking treatment, building relationships and gaining the trust of these patients is essential if the necessary medical information is to be secured. A total of 14 respondents (18.9\%) practiced doctor-centered communication, which implies that they are more interested in medical problem solving. Only one (1.4\%) fell into the doctor-centered communication practice at a low level, which can be considered as practicing patient at low level, which can be considered as practicing patient-centered communication. The mean for doctorcentered is 3.419 compare to 1.581 for low doctor-centered.

Table 1 Communication Style

\begin{tabular}{|l|c|c|c|}
\hline Communication Style & Range & $\boldsymbol{f}$ & \% \\
\hline High (Doctor centred) & $3.68-5.00$ & 14 & 18.9 \\
\hline Medium (Doctor-Patient) & $2.34-3.67$ & 59 & 79.7 \\
\hline Low (Patient-centred) & $1.00-2.33$ & 1 & 1.4 \\
\hline Total & & 74 & 100 \\
\hline
\end{tabular}




\subsection{Information Seeking}

Interview skills (exploration, history, solutions) showed that the majority of respondents, $46 / 74(62.1 \%)$, practice interview skills in exploration at a high level. Meanwhile, the practice skills of 26 respondents $(35.2 \%)$ can be rated as average. Only three respondents practice the skills of exploration at low level.

Concerning historical understanding, almost the entire sample, 72/74 (97.2\%) practice interview skills at a high level. Only two doctors $(2.8 \%)$ practice the skills at an intermediate level. None of the respondents practiced the skills of historical understanding at low levels. Concerning processing skills (structuring, interpersonal relationships and communication) more than half the respondents practice skills restructuring process at a high level, or 39/74 (52.7\%). Of the remainder, 34 respondents (46\%) practice skills rated as average, and only one $(1.4 \%)$ respondents $(46 \%)$ practice skills rated as average, and only one (1.4\%) respondent was rated as low-level.

The majority of respondents practice process skills in interpersonal relationship skills at the highest level, with $47 / 74$ respondents $(63.5 \%)$. A total of $24 / 74(32.4 \%)$ respondents are rated as average, and only $3(1.04 \%)$ practice the skills of interpersonal relationships at low level. For communicative skills, 46/74 (63.5\%) practice at a high level. Of the remainder, $25(33.8 \%)$ respondents practice the skills at the medium level and only three (4.1\%) practice communicative skills at low level.

\subsubsection{Information Seeking At High Level}

Table 2 below summarizes the comparison of high level of information seeking skills. In the interview skill of information seeking, high percentages were displayed in all three elements in this section: exploration was $62.1 \%$, historical understanding was $97.2 \%$ and providing a concrete solution came in at $90.5 \%$. For the retrieval of information processing skills, the results of the three elements showed structuring the interview at $52.7 \%$, interpersonal relations at $63.5 \%$ while communication was rated at $62.5 \%$

Table 2 Level of Information Seeking

\begin{tabular}{|c|c|c|c|}
\hline \multicolumn{2}{|c|}{ Information seeking skills (Interviews) } & \multicolumn{2}{c|}{ Information seeking skills (Process) } \\
\hline Exploration & $62.1 \%$ & Structure Interviews & $52.7 \%$ \\
\hline History taking & $97.2 \%$ & Interpersonal relationships & $63.5 \%$ \\
\hline Concrete solution & $90.5 \%$ & Communicative & $62.5 \%$ \\
\hline
\end{tabular}

\subsection{The Combination Of Doctor-Centred And Patient-Centred Style And Information Seeking Practice}

From the data obtained, determining the most dominant communication pattern is derived as follows: to plot the quadrant, as expressed in percentage, the mean values for each element of the study of doctor-centered communication, patient-centered communication, information seeking-exploration, information seeking-history taking, information seeking-concrete solution, information seeking-structure interview, information seeking-interpersonal relationship and information seeking-communicative skill are used.

In the doctor-centered and patient centered communication styles, the mean value obtained for both styles is, respectively, 3.419 and 1.581. The mean score was divided by the highest mean and multiplied by 100 (e.g. 3.419/5.0 x 100).

Data derived from the research, and expressed in percentages, show that on the whole, doctor-centered communication style was adopted by $68.38 \%$ of the respondents, while the reminder, $31.62 \%$, practice patient-centered communication style when communicating with their patients.

To identify patterns of information seeking, researchers use the same method. The mean value for each element in the information seeking skills divided by the highest score and multiplied by 100 .

For the interview skills of information seeking, the average scores as shown by all respondents during the course of explorations skills is $74.38 \%(5.95 / 8 \times 100)$, history taking 87.39 (20.1/23 x 100), concrete solutions $84.17(10.1 / 12 \times 100)$. All three scores summed and divided by three to get overall interview skills. The overall score obtained was $81.98 \%(74.38+87.39+87.17 / 3)$ and this shows that more respondents practice interview skills in information seeking skills when with their patients.

For processing skills, the scores shown by all respondents during the course of the structured interview is $72.5 \%(5.8 / 8 \mathrm{x} 100)$, interpersonal relationship $79(7.9 / 10 \times 100)$ and communicative $81.43(5.7 / 7 \times 100)$. The overall score obtained was $77.64(72.5+79+$ $81.43 / 3$ ), shows that the respondents practice 77.64 of their processing skills in information seeking.

Based on Figure 2, the majority of respondents are practiced doctor-centered and practiced skills interview and process interview in information seeking at high level (Quadrant A and B) although doctor centered and interview skills (Quadrant A) is the highest. This means that respondents use more doctor-centered communication practices in the search for necessary information in medical communication with their patients. Figure also demonstrates that the respondents were practicing patient-centered communication style at low levels in the process of finding the required information in medical communication with their patients. 


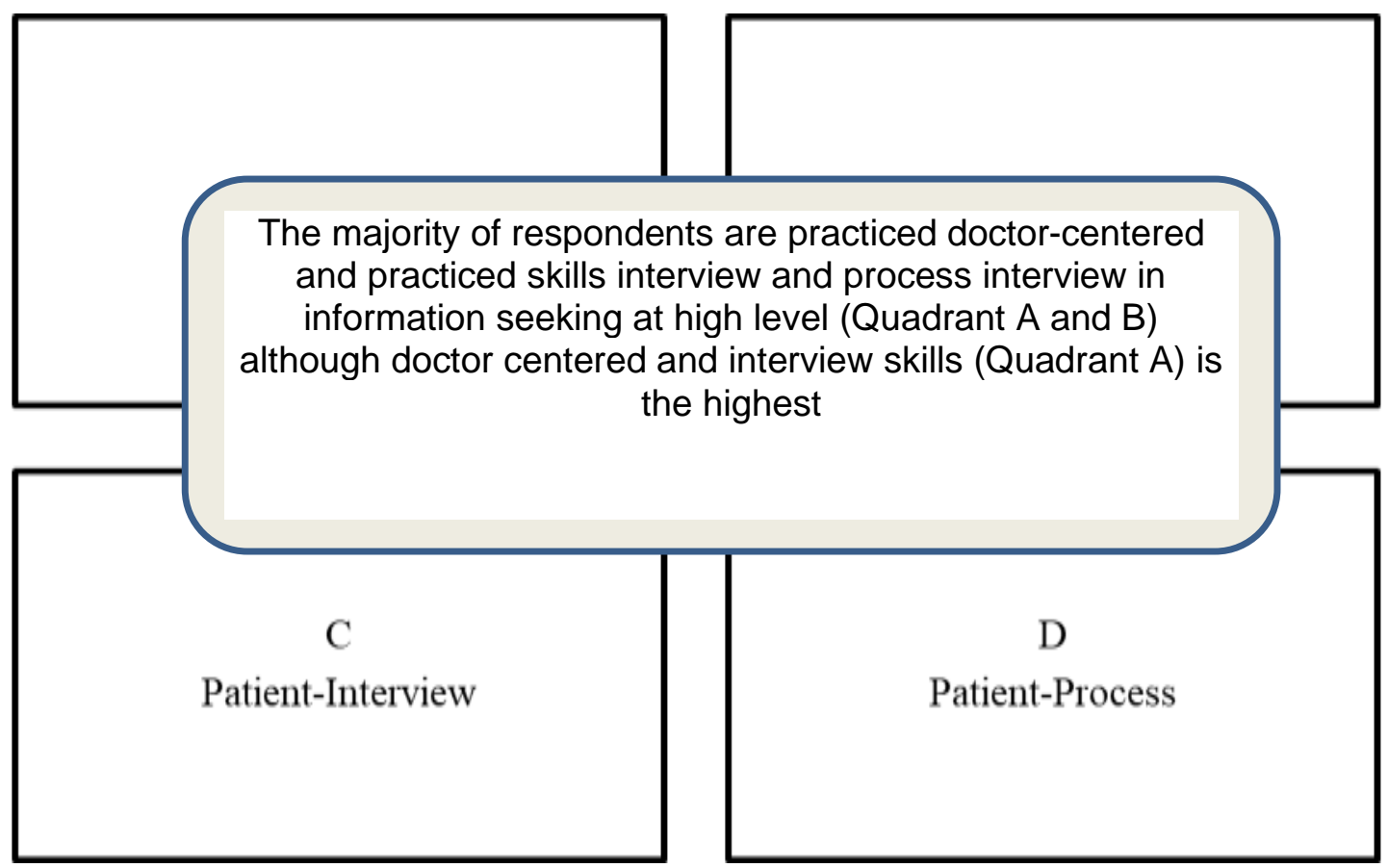

Figure 2 Malaysian Junior Doctors Communication and Information seeking

\subsection{DISCUSSION AND RECOMMENDATION}

The first objective is to identify the doctor-patient communication pattern adopted by housemanship or junior doctors. Based on a five scale mean, the scores for doctor centered and patient centered communication is 3.419 and 1.58 respectively. This indicates that the communication pattern as practiced by junior doctors is doctor centered than patient centered

This finding is in line with the research findings of Symone et al. (2001) and Sachiko, Toshio and Michael (2003). Symone et al found that doctors spend $64 \%$ of the time with their patients discussing cancer problems, and only $23 \%$ of the time trying to understand the emotional and social lives of their patients who face with the cancer problem. Sachiko et al (2003) found that Japanese doctors spent $28 \%$ of their time on medical check, and only $15 \%$ of time on brief chats with their patients. Japanese doctors were also found to be silent during $30 \%$ of the entire time spent with their patients. The study also provides evidence that doctors in Japan exercise more control of the communication session $(78 \%)$ by asking more questions of their patients. Based on the above discussion, many medical doctors adopt doctor-centered communication compare to patient-centered communication. This scenario may occur due to the weak interpersonal communication skills of medical practitioners (Hersen \& Turner, 2003).

What should doctors change about the way they communicate? Street (2003) asserts that patients treated by a doctor who practices patient-centered communication style prefer to actively participate in discussions with their doctor such as asking more questions, compared with patients treated by doctors who practice doctor-centered communication. In their study, they found that patients who are actively involved in discussions about their medical management will ask for opinions and advice of the doctors who treat them. Patients find it much easier to see a doctor who shares information with them. As a result, patient actively participates by asking more questions in order to better understand the situation.

The second objective is to identify information seeking practice adopted by junior doctors. Information seeking based on skills interviews, shows respondents practiced at high level. One of the elements studied in the interview skills is history taking. This study indicates that the element of history taking is implemented at a very high level by respondents (97.2\%). The result obtained, is contrary to the study by Papp et al. (2001). Furthermore, $90.5 \%$ of respondent carry out almost all the skills in element of the concrete solution. The elements include explaining the problems faced by patients in a way that it easy to understand, explaining the causes of disease, providing information about a disease in detail, providing recommended troubleshooting steps, discussing the pros and cons of solutions, and making sure the patient understands the advice given at the highest level of competence. The findings are consistent with studies conducted by Braddock et al. (1977), who's finding show that respondents, in $83 \%$ of their sessions with patients, discuss the patient problems and offer solutions. Among the three elements of interview skills exploration is the lowest for high level information seeking practice. Only $62.1 \%$ of the respondents practiced exploration at high level. However total score for interview skills is $83.2 \%$ at high level.

Information seeking practice for process skills is lower than interview skills. The total score for this category is $59.6 \%$ for high level practice. Process skills consist of structuring interview, interpersonal relationship and communicative. The respondents are implementing elements such as facilitating the communication process, show an appropriate sense of empathy to patients, ask how the patients feel during the communication process in progress and also make patients feel comfortable. The finding of the study showed that the percentage of high level elements of the process skills is not that high. The percentage of the implementation process skill indicated by the respondents is only slightly ranging from $50 \%$ to $64 \%$. This finding is in line with the findings of research conducted by Emran Rouf et al. (2008) who carried out a review of third year medical students at School of Medicine, University of Kansas using video analysis. The 
study indicated that the respondents exhibited poor interpersonal communication skills. Only about $30 \%$ scored well on this element, when the score should have been closer to $85 \%$.

The third objective is the main objective for this study. The objective is to identify dominant patterns of doctor-patient communication styles and information seeking by junior doctors to develop a model base on four quadrants. Respondents was found to be more doctor-centered, or Quadrant A and Quadrant B. The respondents practicing this type of communication tend to control communication sessions with their patients. The respondents give more medical information and advice on how to prevent a disease from recurring. However, from these two quadrants represent the doctor-centered, most respondents were found in the Quadrant A. Information seeking as practiced by the respondents including in the Quadrant A, are focused on the types of illness and pain experienced by their patients. The respondents in this category use more closed questions, provide more advice to their patients and do not give space to their patients to be involved in the communication process between doctor and patient.

In addition, many respondents who were classified in Quadrant B have the tendency to use doctor-centered communication style and are more controlling in communication sessions with their patients. The respondents also give more medical information and advice about how to prevent a disease from recurring. Information seeking skills, as practiced by the respondents as classified in this quadrant, are focused on the information search process. Many respondents are using good communication skills such as working to create an environment that is comfortable to their patients. They provide the information required by the respondents to understand the patient's condition.

Respondents who were classified in this category often use closed questions, provide more advice to their patients, and do not give much space to their patients to become involved in the communication process between doctor and patient. However, most of the respondents are capable of displaying empathy and emotion at times.

Only a few respondents were identified as belong to Quadrants C and D. This is because not many of the respondents practice patient-centered communication. Respondents belong to these quadrants are more likely to use patient-centered communication style, in which respondents are more likely give their patients the opportunity to interact and provide information related to the problems they face.

The difference between the two quadrants lies in the information seeking as practiced by the respondents. Respondents in Quadrant $\mathrm{C}$, are more interested in the medical issues experienced by their patients. Respondents who were classified in this category spent more time asking open questions and providing more opportunities for their patients to be involved in in the communication process between doctor and patient.

Respondents in Quadrant D show better communication skills, such as working to create more comfortable environment for patients, motivating their patients to participate actively in discussions, and providing the information that they, the respondents, need to better understand the patient's condition. The respondents in this category often use open ended questions, provide more opportunities for their patients to be involved in the communication process, and can be empathic and emotional at times.

\subsection{CONCLUSION}

Effective communication in the field of health care has been proven to help increase patient satisfaction, providing a positive effect on health as well as helping patients become more compliant during their treatment sessions. There is growing acceptance of the need to promote the teaching and assessment of communication skills in medical schools across the country.

Teaching communication skills in the medical field is actually more difficult than other fields. This is because communication skills involve not only the interaction between doctor and patient, but the exchange of information itself, whether orally or in writing (report). In addition, interactions also exist with the patient's family and fellow health care professionals.

Through this research, we identified the pattern or style of junior doctor's communication and have built a model of doctor's communication orientation and styles with their patients which can rate, or measures, skills in information seeking among the doctors. This model based on four quadrants namely doctor-interview, doctor-process, patient interview and patient-process

\section{References}

Abor, P.A. (2019). Exloring Clinical Communication in a Teaching Hospital in Ghana. International Journal of Health Governance, 24(2),155-168

Anderson, L.A. \& Sharpe, P.A. (1991). Improving Patient and Provider Communication: A Synthesis and Review of Communication Interventions. Patient Education and Counseling, 17(2), 99-134.

Ballard-Reisch, D.S. (1990). A Model of Participative Decision Making for Physician-Patient Interaction. Health Communication, 2 (2), 91 -104.

Beckman, H.B. \& Frankel, R.M. (1984). The Effect of Physician Behavior on the Collection of Data. Annals of Internal Medicine, 101(5), 692-696.

Belasen, A. \& Belesen, A.T. (2018). Doctor-Patient Communication: A Review and a Rationale for Using an Assessment Framework. Journal of Health Organization and Management, 32(7), 891-907.

Braddock III, C.H., Fihn, S.D., Levinson, W., Jonsen A.R. \& Pearlman, R.A. (1997). How Doctors and Patients Discuss Routine Clinical Decision: Informed Decision Making in the Outpatient Setting. Journal of General Internal Medicine. 12 (6), 339-345.

Cerimagi, S.; Ahmadi, N., Gurney, H. \& Patel, M.I (2015). Doctor-patient Communication: A Study of Australian Ethnic Urological Cancer Patients. International Journal of Human Rights in Healthcare, 8(2), 82-91.

Choudhary, A. \& Gupta, V. (2015). Teaching Communications Skills to Medical Students: Introducing the Fine Art of Medical Practice. International Journal of Applied Basic Medical Research, 5(1), 41-44.

DiMatteo, M.R., Sherbourne, C.D., Hays, R.D., Ordway, L., Kravitz, R.L., McGlynn, E.A., Kaplan, S. \& Rogers, W.H. (1993). Physicians' Characteristics Influence Patients' Adherence to Medical Treatment: Result from the Medical Outcome Study. Health Psychology, 12 (2), 93-102.

Gordon, S (2020). 3 Ways Tell if Your Doctor Has a Patient-centered Focus. Very Well Health. https://www.wellhealth.com. Retrieved on 14 April 2021.

Graf, J. Loda,T., Zipfel, S., Wosnik, A. Mohr, D. \& Herrmann-Werner, A. (2020). Communication Skills of Medical Students: Survey of Self- and External Perception in a Longitudinally Based Trend Study. BMC Medical Education, 20(1). DOI:10.1186/s12909-020-02049-w

Graugaard, P.K. \& Finset, A. (2000). Trait Anxiety and Reactions to Patient-Centered and Doctor-Centered Styles of Communication: An Experimental Study. Psychosomatic Medicine. 62(1), 33-39.

Hersen, M. \& Turner, S.M. (2003). Diagnostic Interviewing ( $3^{\text {rd }}$ ed). New York: Kluwer Academic. 
Hildenbrand, G.M., Perrault, E.K. \& Keller, P.E. (2020). Evaluating a Health Literacy Communication Training for Medical Students: Using Plain Language. Journal of Health Communication. 25(8), 624-631.

Laerum, E., Steine, S., Finckenhegen, M. \& Inset, A. (2002). The Final Version of the Patient Perspective Survey (PPS): A Tool to Improve Consultation Outcome an Patient Participation in General Practice Patients with Complex Health Problems, Doctors and Patients' Evaluation and Guidelines for Clinical Use. International Journal of Family Practice, 19 (3), 264-271

Manning, P. \& Ray, G.B. (2002). Setting the Agenda: An Analysis of Negotiation Strategies in Clinical Talk. Health Communication, 14(4), 451-473.

Marvel, M.K., Epstein, R.M., Flowers, K. \& Beckman, H.B. (1999). Soliciting the Patient's Agenda: Have We Improved? Journal of American Medical Association, $28(3), 283-287$.

Novack, D.H., Volk, G., Drossman,D.A. \& Lipkin Jr, M. (1993). Medical Interviewing and Interpersonal Skills Teaching in US Medical Schools: Progress, Problems and Promise. Journal of American Medical Association, 269(16), 2101-2105.

Papp, K.K., Erokwu, B., Decker, M. \& Strohl, K. (2001). Medical Student Competence in Eliciting a History for "Chronic Fatigue, Journal of Sleep and Breathing, 5(3), 123-129.

Platonova, E.A. \& Shewchuck, R.M. (2015). Pattient Assessment or Primary Care Physician Communication: Segmentation Approach. International Journal of Health Care Quality Assurance. 28(4), 332-342.

Powell, L. \& Amsbary, L. (2006). Interviewing: Situations and Contexts. Boston: Pearson. Robinson, J.D. (2003). An Interactional Structure of Medical Activities During Acute Visits and it Implications for Patients' Participation. Health Communication, 15 (1), $27-57$.

Robson, A. \& Robinson, L. (2015). The Information Seeking and Communication Model: A Study of its Practical Application in Healthcare. Journal of Documentation. 71(5), 1043-1069.

Rouf, E., Chumley, H \& Dobbie, A. (2008). Patient-centered interviewing and student performance in a comprehensive clinical skills examination: Is there an association? Patient Education and Counseling, 75(1), 11-5. .

Sachiko, O., Toshio, O., \& Michael, D.F. (2003) Doctor-Patient Communication: A Comparison of the USA and Japan, Family Practice, $20(3), 276-282$.

Safran, D.G., Montgomery, J.E., Chang, H., Murphy, J. \& Rogers, W.H. (2001). Switching Doctors: Predictors of Voluntary Dis-Enrollment from a Primary Physician's Practice, Journal of Family Practice, 50(2), 130-136.

Smith, R.C. \& Hoppe, R.B. (1991). The Patient's Story: Integrating the Patient-Centered and Physician-Centered Approaches to Interviewing. Annals of Internal Medical, 115(6), 470-477.

Smith, R.C., Lyles, J.S., Metter, J., Stoffelmayr, B.E., Van Engeren, L.F., Marshall, A.A., Gardiner, J.C., Maduschke, K.M., Stanley, J.M., Osborn, G.G., Shebroe, V. \& Greenbaum, R.B. (1998). The Effectiveness of Intensive Training for Residents in Interviewing Skills: A Randomized Controlled Study, Annals of Internal Medicine, 128(2), 118-126.

Stewart, M. \& Roter, D. (1989). Communicating with Medical Patients. Newbury Park: Sage Publication.

Stewart, M.A. (1995). Effective Physician-patient Communication and Health outcome: A Review, Journal of Canada Medical Association, 152 (9), $1423-1433$.

Stewart, M., Brown, J.B., Hammerton, J., Donner, A., Gavin, A., Holiday, R.L., Whelan, T., Leslie, K., Cohen, I., Wetson, W. \& Freeman, T. (2007). Improving Communication Between Doctors and Breast Cancer Patients.,Annals of Family Medicine, 5 (5), 387-394.

Street Jr, R.L., Krupat, E., Bell, R.A., Kravitz, R.L. \& Haidet, P. (2003). Beliefs About Control in Physician-Patient Relationship Effect on Communication in Medical Encounters. Journal of General Internal Medicine, 18(8), 609-616.

Suchman, A.L., Markakis, K., Beckman, H. \& Frankel, R. (1997). A Model of Empathic Communication in the Medical Interview, Journal of American Medical Association, 227 (8), 678-682.

Symone, B.D., Martin, J.M., Liowina, D.V.W., Jan, H.S. \& Neil, K.A. (2001). Patient-Physician Communication During Outpatient Palliative Treatment Visits, The American Journal of the Medical Association, 285 (10), 1351-1357.

Takayama, T., Yamazaki, Y., \& Katsumata, N. (2001). Relationship Between Outpatients' Perception of Physicians' Communication Styles' and Patients' Anxiety Level in Japanese Oncology Setting. Social Science Medication, 53(10), 1335-1350.

Tate, P. (2007). The Doctor's Communication Handbook ( $\left.5^{\text {th }} \mathrm{ed}\right)$. Oxford: Radcliffe Publishing.

Taveira-Gomesa, I., Mota-Cardosoa, R., Figueiredo-Bragaa, M. (2016). Communication Skills in Medical Students: An Exploratory Study Before and After Clerkships. Porto Biomedical Journal. 1(5), 173-180. DOI: 10.1016/j.pbj.2016.08.002

Virshup, B.B., Oppenberg, A.A. \& Coleman, M.M. (1999). Strategic Risk Management: Reducing Malpractice Claims Through More Effective Patient-Doctor Communication. American Journal of Medical Quality, 14(4), 153-159.

Waitzkin, H. (1985). Information Giving in Medical Care. Journal of Health and Social Behaviour, 26 (2), 81-101.

Weaver, R.R. (2003). Informatics Tools and Medical Communication: Patient Perspectives of Knowledge Coupling in Primary Care, Health Communication, 15 (1), 59-78.

Wu, Q.L., \& Street Jr, R.L. (2020). The Communication Ecology of Chinese Patients Experiences with Healthcare. Journal of Health Communication. 25(6), 463-473.

Young, A. \& Flower, I. (2001). Patients as Partners, Patient as Problem-Solvers, Health Communication, 14 (1), 69-97. 